\title{
HYGIENIC ASSESSMENT OF THE EFFECTIVENESS OF USING DISTANCE EDUCATIONAL TECHNOLOGIES IN MEDICAL EDUCATION
}

Markelova SV ${ }^{1}$, Fedotov DM² ${ }^{凶}$, Khromova $\mathrm{AV}^{2}$, levleva OV

Pirogov Russian National Research Medical University, Moscow, Russia

${ }^{2}$ Northern State Medical University, Arkhangelsk, Russia

The aim of this study was to assess the impact of distance learning technologies (DLTs) on the daily routine and health of medical students during the COVID-19 pandemic. The questions included in the questionnaire were intended to measure the awareness of students about the risks associated with distance learning (DL), elicit their opinion about the organization of the learning process and subjectively assess DL as such. The study was conducted in December 2020 . It enrolled 508 medical students of Pirogov Russian National Research Medical University (Moscow) and of Northern State Medical University (Arkhangelsk). Statistical analysis was performed in Statistica 13.0. For categorical variables, the significance of differences was assessed using Pearson's chi-square test. Differences were considered significant at $p \leq 0.05$. The analysis reveals that $80 \%$ of the respondents thought that DLTs were implemented effectively. The dynamics of academic performance were used as an objective indicator of content assimilation. No significant differences were discovered in the academic performance of students before, during and after the DL period. Although medical students are ready to use some elements of DLTs in the learning process, there is a need for introducing active teaching methods, refining teaching strategies, perfecting teaching skills and teaching students competencies that can be used to maintain their health in the classroom and in a distance learning setting.

Keywords: students, electronic devices, distance learning

Author contribution: Markelova SV, Fedotov DM — article writing; Khromova AV, levleva OV — collection of material, statistical processing, analysis of literature.

Compliance with ethical standards: this study was approved by the LEK Russian National Research Medical University named after V.I. N.I. Pirogov (Protocol № 203 dated 20.12.2020). Voluntary informed consent was obtained for each participant. The online survey for the adult population was conducted on a voluntary basis using an online service. The conducted research does not endanger the participants and complies with the requirements of biomedical ethics.

$\triangle$ Correspondence should be addressed: Denis M. Fedotov

Prospect Troitsky, 51, Arkhangelsk, 163000; doctorpro@yandex.ru

Received: 25.03.2021 Accepted: 28.03.2021 Published online: 31.03.2021

DOI: $10.24075 /$ rbh.2021.007

\section{ГИГИЕНИЧЕСКАЯ ОЦЕНКА ЭФФЕКТИВНОСТИ ИСПОЛЬЗОВАНИЯ ДИСТАНЦИОННЫХ ОБРАЗОВАТЕЛЬНЫХ ТЕХНОЛОГИЙ В МЕДИЦИНСКОМ ОБРАЗОВАНИИ}

\author{
С. В. Маркелова ${ }^{1}$, Д. М. Федотов ${ }^{\natural}$, А. В. Хромова², О.В. Иевлева ${ }^{1}$
}

${ }^{1}$ Российский национальный исследовательский медицинский университет им. Н.И. Пирогова, Москва, Россия

${ }^{2}$ Северный государственный медицинский университет, Архангельск, Россия

\begin{abstract}
Целью исследования являлась гигиеническая оценка использования дистанционных образовательных технологий (ДОТ) обучающимися медицинского ВУЗа в период пандемии COVID-19. Были разработаны анкеты, содержащие вопросы по уровню информированности обучающихся о факторах риска, связанных с проведением дистанционного обучения (ДО), об организации педагогического процесса в период ДО и субъективной оценке ДО. Исследование проведено в декабре 2020 года. В нем приняли участие 508 обучающихся ФГАОУ ВО РНИМУ им. Н.И. Пирогова и ФГБОУ ВО СГМУ (г. Архангельск). Статистическая обработка данных проведена с использованием Statistica 13.0. Статистическую значимость различий качественных данных оценивали с помощью критерия хи-квадрат Пирсона. Критический уровень значимости принимали при p $\leq 0,05$. Результаты свидетельствуют о том, что положительную субъективную оценку эффективности реализации ДОТ в период пандемии COVID-19 дали $80 \%$ опрошенных. В качестве объективного критерия усвоения материала при реализации ДОТ было проведено изучение динамики успеваемости опрошенных. Нами не выявлень статистически значимые различия в динамике успеваемости обучающихся до, во время и после перехода на ДО. Таким образом несмотря на высокую готовность обучающихся медицинского ВУЗа к использованию элементов ДОТ в образовательном процессе, требуется совершенствование форм преподавания, внедрение активных форм, совершенствование умений профессорско-преподавательского состава и формирование у обучающихся компетенций, связанных со здоровьесбережением, которые они могут реализовывать как при очном, так и при До.
\end{abstract}

Ключевые слова: обучающиеся, электронные устройства, дистанционное обучение

Вклад авторов: Маркелова С. В., Федотов Д. М. - написание статьи; Хромова А. В., Иевлева О. В. - сбор материала, статистическая обработка, анализ литературы.

Соблюдение этических стандартов: Данное исследование было одобрено ЛЭК РНИМУ им. Н.И. Пирогова (Протокол № 203 от 20.12.2020). Добровольное информированное согласие было получено для каждого участника. Проведение онлайн-опроса для взрослого населения проводилось на добровольной основе, с использованием онлайн-сервиса. Поведенное исследование не подвергает опасности участников и соответствует требованиям биомедицинской этики.

$\bowtie$ Для корреспонденции: Федотов Денис Михайлович

пр-т Троицкий, д. 51, г. Архангельск, 163000; doctorpro@yandex.ru

Статья получена: 25.03.2021 Статья принята к печати: 28.03.2021 Опубликована онлайн: 31.03.2021

DOI: $10.24075 /$ rbh.2021.007

The experience of delivering medical education through distance learning technologies (DLTS) during the COVID-19 pandemic which broke out in 2020 is yet to be understood. Although DLTs have been proved to facilitate the learning process, there are still doubts whether students and teachers are ready to use DLTs on a regular basis $[1,2]$. According to a recently published meta-analysis, hybrid education, i.e. the combination of inperson classroom instruction and online learning, results in better knowledge assimilation by medical students in comparison with purely in-person or purely online learning [3]

Maintaining and improving student health is a priority, so the impact of DLTs on student health should be thoroughly 
investigated. Higher education institutions play the leading role in shaping the personality of tomorrow's doctors and their competencies, even when faced with the challenges of DL $[4,5]$.

The aim of this study was to assess the impact of DLTs on the daily routine and health of medical students during the COVID-19 pandemic.

\section{METHODS}

The Department of Hygiene (Faculty of Pediatrics, Pirogov Russian National Research Medical University) designed an online survey distributed via Google Forms [6]; the authors of the survey were qualified in general hygiene, hygiene education, hygiene of children and adults, and epidemiology. The questions were intended to measure the awareness of students about the risks associated with DL, assess the organization of the learning process and elicit students' opinion about online education as such.

The study was conducted in December 2020 and enrolled 508 first to sixth year students of Pirogov Russian National Research Medical University (Moscow) and Northern State Medical University (Arkhangelsk). The mean age of the respondents was 20.5 years; $80 \%$ of the respondents were females. The study included students who gave informed consent to participate and returned clearly and accurately filled-in questionnaires. Exclusion criteria: not being a student, no informed consent to participate, the questionnaire form filled out incorrectly.

The study was approved by the Ethics Committee of Pirogov Russian National Research Medical University (Protocol No. 203 dated December 20, 2020). The study did not pose any health risks for the participants and met the standards of biomedical ethics.

Statistical analysis was carried out in Statistica 13.0 (StatSoft Inc.; USA). For categorical variables, the significance of differences was assessed using Pearson's chi-square test. The effectiveness of DLT implementation was assessed using regression analysis. Differences were considered significant at $p \leq 0.05$.

\section{RESULTS}

The survey revealed that $98 \%$ of the respondents did not have any difficulty using DLT because they were initially gadget-savvy and their ICT (information and communication technologies) skills were quite good.

When assessing the benefits of transitioning to DL, the students indicated that they did not have to use public transport and that DLTs were a time-saver (27\%); they also found they had more time on their hands that could be spent on studies, sleep (24.5\%) and work (20\%); $10 \%$ of the respondents underscored the convenience of using ICT for learning and the high quality of online lectures.

The downsides of $\mathrm{DL}$ included the lack of skill practice (34.5\%), declining motivation to study (15\%), the absence of inperson communication with faculty and other students (15\%), health problems (13\%), and technical issues, such as the availability of electronic devices, workstation-related problems, problems with Internet access, poor ICT skills, etc. (5\%).

When describing their daily routine and leisure activities during the distance learning period, $60 \%$ of the respondents reported they had more free time and $63 \%$ of the respondents reported an improvement in their daily routine. Of those respondents who had a part-time job (35.5\%), 68.5\% reported that it was easier for them to combine work and studies during the distance learning period. Faculty efforts were positively recognized by $70 \%$ of the participants.

A medical student has to master a variety of very complicated disciplines. So, the respondents were asked to name subjects that could not be mastered through purely online education. The list included anatomy, histopathology, biochemistry, pathological anatomy, topographic anatomy, emergency surgery, clinical subjects like internal diseases and pediatrics. DL-related stress and adaptation difficulties were reported by $17 \%$ of the respondents; $64.2 \%$ of the respondents reported that it took them longer to do their homework during the DL period.

The regression model $(p=0.017)$ describing the subjective assessment of students' emotional attitude to DL (values $>1$ point designate positive attitude, values $<1$ point designate negative attitude) does not contain variables associated with age, sex, year of study, academic performance, the ability to use electronic devices, and technology requirements for distance learning. The equation contains variables (1) associated with the absence of stress during the transition to DL, appreciation of the form in which learning materials were presented, and relationships between peers and between students and faculty:

$Y=0.73+0.22 X 1+0.18 X 2+0.09 X 3-0.21 X 4-0.12 X 5-$ $0.14 \times 6$ (1), where

$\mathrm{X} 1$ is the absence of stress during the transition to $\mathrm{DL}$;

$\mathrm{X} 2$ is the appreciation of the form in which learning materials were presented (the high quality of online lectures and classes);

$\mathrm{X} 3$ is the opportunity to combine work and studies;

$\mathrm{X} 4$ is the negative impact on daily routine and less free time due to spending more time on home assignment;

X5 designates a declining relationship between peers;

X6 designates a declining relationship between students and faculty.

That said, the quality of distance learning implementation can be inferred from the assessment of its effectiveness by students. The regression model $(p=0.001)$ describing the subjective assessment of DL effectiveness by students (values $>3$ points indicate positive assessment) contains variables (2) associated mostly with the organization of the learning process and faculty efforts:

$Y=2.76+0.13 \times 1+0.21 X 2+0.22 X 3-0.14 X 4-0.19 \times 5-$ $0.14 \times 6$ (2), where

$\mathrm{X} 1$ is good health (self-assessment);

$\mathrm{X} 2$ is an improvement in daily routine and more free time;

$\mathrm{X} 3$ is the appreciation of faculty efforts;

$\mathrm{X} 4$ is difficulty adapting to $\mathrm{DL}$;

$\mathrm{X} 5$ is a dislike of learning material presentation;

$\mathrm{X} 6$ is a dislike of knowledge assessment formats.

On the whole, $80 \%$ of the respondents thought that DLTs were implemented effectively.

The subjective assessment of DLT implementation reflects the student's perception, in the first place. Another important indicator of knowledge assimilation is the dynamics of academic performance. We asked the respondents to evaluate their academic performance before, during and after the distance learning period. The analysis of the obtained data did not reveal any significant differences in the dynamics of the learning process.

The number of students with excellent performance was stable $(7.7 \% \pm 1.2 \%)$. The same was true for the respondents with excellent or good performance $(55.3 \pm 5.0 \%, 64.2 \pm 5.0 \%$, $56.5 \pm 5.0 \% ; p=0.21)$. The proportion of students whose performance was different from good or excellent (e.g. satisfactory) remained unchanged, too. However, some students reported poor academic performance during and after the distance learning period. This can be explained by 
decreased motivation to study online, difficulty self-disciplining and technical issues.

Of all students who had experienced DL, $78.7 \%$ said they would prefer in-person classroom learning, with small additions of DLTs. According to $66.7 \%$ of the respondents, the combination of traditional learning formats and DLTs could improve content assimilation. Only $9.8 \%$ of the students were opposed to using DLTs in the learning process.

Thus, medical students are ready to use DLTs in the learning process if they are not stressed, experience no adaptation difficulties, do not suffer from declining relationships between each other and faculty, and the learning process is organized (to the greatest possible extent) in a traditional manner (traditional presentation of learning materials, traditional knowledge assessment formats, having an opportunity to interact with teachers). About $47.8 \%$ of the respondents mentioned the need for being able to use and incorporating health-friendly technologies in the learning process.

\section{DISCUSSION}

DLTs involving the use of stationary and mobile electronic devices that impact students' health are a new element of the learning process $[7,8,9,10]$.

Foreign publications have identified a number of problems in teaching medical students. The integration of DLTs into the learning process has uncovered the ambivalence of traditional and active teaching methods, which raised concerns about their impact on different aspects of life [11, 12].

It was reported that the majority of medical students felt positive about transitioning to DL; however, this was not the case with small groups, including autopsy sessions. Less than a half of the respondents developed symptoms of anxiety [13, 14].

Active learning technologies allow both students and teachers, who should be able to use them in the learning process, to adapt to online education and offer a few extra advantages that ensure a flexible, dynamic, mobile, sustainable and culturally safe learning environment [15].

Teachers are expected to be competent and skilled in using various online learning platforms $[16,17]$.

\section{CONCLUSIONS}

This study demonstrates that medical students are ready to use some elements of DLTs in the learning process. However, such technologies raise the need for active teaching methods, refined teaching strategies and perfected teaching skills. The special focus should be placed on identifying students who find DLT challenging. It is imperative that students should be taught competencies that can be used to maintain their health in the classroom and in a distance learning setting.

\section{References}

1. Popov VI, Milushkina OYu, Skoblina NA, Markelova SV, Sokolova NV, Dement'ev AA. Povedencheskie riski zdorov'yu studentov $\checkmark$ period provedeniya distantsionnogo obucheniya. Gigiena i sanitariya. 2020; 99 (8): 854-860. Russian.

2. Milushkina OYu, Popov VI, Skoblina NA, Markelova SV Sokolova NV. Ispol'zovanie elektronnykh ustroystv uchastnikami obrazovatel'nogo protsessa pri traditsionnoy i distantsionnoy formakh obucheniya. Vestnik Rossiyskogo gosudarstvennogo meditsinskogo universiteta. 2020; (3): 85-91. Russian.

3. Liu Q, Peng W, Zhang F, Hu R., Li Y, Yan W. The Effectiveness of Blended Learning in Health Professions: Systematic Review and Meta-Analysis. J Med Internet Res. 2016; 18(1): e2 DOI: 10.2196/ jmir.4807.

4. Glybochko PV, Esaulenko IE, Popov VI, Petrova TN. Zdorov'e studentov meditsinskikh vuzov Rossii: problemy i puti ikh resheniya. Sechenovskiy vestnik. 2017; (2): 4-11. Russian.

5. Evdokimov VI, Gubina OI, Popov VI, Bocharov VV, Tupitsyn YuYa, Zhuk SP. Metodika otsenki psikhicheskogo zdorov'ya i pokazateli adaptatsii studentov Voronezhskoy gosudarstvennoy meditsinskoy akademii imeni N.N. Burdenko. Sistemnyy analiz i upravlenie v biomeditsinskikh sistemakh. 2005; 4 (4): 457-60.

6. Pivovarov YuP, Skoblina NA, Milushkina OYu, Markelova SV, Fedotov DM, Okol'nikov FB i dr. Ispol'zovanie internet-oprosov $\checkmark$ otsenke osvedomlennosti ob osnovakh zdorovogo obraza zhizni. Sovremennye problemy zdravookhraneniya i meditsinskoy statistiki. 2020; (2): 398-413. Russian.

7. Popov VI, Libina II, Gubina OI. Problemy sovershenstvovaniya optimizatsii uchebnogo protsessa v meditsinskom vuze. Zdorov'e - osnova chelovecheskogo potentsiala: problemy i puti ikh resheniya. 2010; 5 (1): 185-186. Russian.

8. Marchuk NYu. Psikhologo-pedagogicheskie osobennosti distantsionnogo obucheniya. Pedagogicheskoe obrazovanie v Rossii. 2013; (4): 75-85. Russian.

9. Kuznetsova OV. Distantsionnoe obuchenie: za i protiv.
Mezhdunarodnyy zhurnal prikladnykh i fundamental'nykh issledovaniy. 2015; 8 (2): 362-364. Russian.

10. Popov MV, Libina II, Melikhova EP. Otsenka vliyaniya gadzhetov na psikhoemotsional'noe sostoyanie studentov. Molodezhnyy innovatsionnyy vestnik. 2019; 8 (2): 676-678.

11. Marsilli LRB., Smecellato FB, Junior OCS. Medical education in COVID-19 pandemic: Medical students' point of view. Medicina. 2020; 53 (4): 490-494.

12. Sindiani AM, Obeidat N, Alshdaifat E, Elsalem L, Alwani MM, Rawashdeh $\mathrm{H}$ et al. Distance education during the COVID-19 outbreak: A cross-sectional study among medical students in North of Jordan. Ann Med Surg (Lond). 2020; (59): 186-194. DOI: 10.1016/j.amsu.2020.09.036.

13. Cuschieri S, Calleja AJ. Spotlight on the shift to remote anatomical teaching during covid-19 pandemic: Perspectives and experiences from the University of Malta. Anat Sci Educ. 2020; 13 (6): 671-679. doi.org/10.1002/ase.2020

14. Rizun M, Strzelecki A. Students' acceptance of the covid-19 impact on shifting higher education to distance learning in Poland. Int J Environ Res Public Health. 2020; 17 (18): 1-19. doi. org/10.3390/ijerph17186468

15. Currie G, Hewis J, Nelson T, Chandler A, Nabasenja C, Spuur K. COVID-19 impact on undergraduate teaching: Medical radiation science teaching team experience. J Med Imaging Radiat Sci. 2020; 51 (4): 518-527. DOI: 10.1016/j.jmir.2020.09.002.

16. Haroon Z, Azad AA, Sharif M, Aslam A, Arshad K, Rafiq S. COVID-19 Era: Challenges and Solutions in Dental Education. J Coll Physicians Surg Pak. 2020; (10): 129-131. DOI: 10.29271/ jcpsp.2020.supp2.129.

17. Chertoff JD, Zarzour JG, Morgan DE, Lewis PJ, Canon CL, Harvey JA. The Early Influence and Effects of the Coronavirus Disease 2019 (COVID-19) Pandemic on Resident Education and Adaptations. J Am Coll Radiol. 2020; 17 (10): 1322-1328. DOI:10.1016/j.jacr.2020.07.022. 


\section{Литература}

1. Попов В. И., Милушкина О. Ю., Скоблина Н. А., Маркелова С. В., Соколова Н. В., Дементьев А. А. Поведенческие риски здоровью студентов в период проведения дистанционного обучения. Гигиена и санитария. 2020; 99 (8): 854-860.

2. Милушкина О. Ю., Попов В. И., Скоблина Н. А., Маркелова С. В., Соколова Н. В. Использование электронных устройств участниками образовательного процесса при традиционной и дистанционной формах обучения. Вестник Российского государственного медицинского университета. 2020; (3): 85-91.

3. Liu Q, Peng W, Zhang F, Hu R., Li Y, Yan W. The Effectiveness of Blended Learning in Health Professions: Systematic Review and Meta-Analysis. J Med Internet Res. 2016; 18(1): e2 DOI: 10.2196/ jmir.4807

4. Глыбочко П. В., Есауленко И. Э., Попов В. И., Петрова Т. Н. Здоровье студентов медицинских вузов России: проблемы и пути их решения. Сеченовский вестник. 2017; (2): 4-11.

5. Евдокимов В. И., Губина О. И., Попов В. И., Бочаров В. В., Тупицын Ю. Я., Жук С. П. Методика оценки психического здоровья и показатели адаптации студентов Воронежской государственной медицинской академии имени Н.Н. Бурденко. Системный анализ и управление в биомедицинских системах. 2005; 4 (4): 457-60.

6. Пивоваров Ю. П., Скоблина Н. А., Милушкина О. Ю., Маркелова С. В., Федотов Д. М., Окольников Ф. Б. и др. Использование интернет-опросов в оценке осведомленности об основах здорового образа жизни. Современные проблемь здравоохранения и медицинской статистики. 2020; (2): 398413.

7. Попов В. И., Либина И. И., Губина О. И. Проблемь совершенствования и оптимизации учебного процесса в медицинском вузе. Здоровье - основа человеческого потенциала: проблемы и пути их решения. 2010; 5 (1): 185-186.

8. Марчук Н. Ю. Психолого-педагогические особенности дистанционного обучения. Педагогическое образование В России. 2013; (4): 75-85.
9. Кузнецова О. В. Дистанционное обучение: за и против. Международный журнал прикладных и фундаментальных исследований. 2015; 8 (2): 362-364.

10. Попов М. В., Либина И. И., Мелихова Е. П. Оценка влияния гаджетов на психоэмоциональное состояние студентов. Молодежный инновационный вестник. 2019; 8 (2): 676-678.

11. Marsilli LRB., Smecellato FB, Junior OCS. Medical education in COVID-19 pandemic: Medical students' point of view. Medicina. 2020; 53 (4): 490-494.

12. Sindiani AM, Obeidat N, Alshdaifat E, Elsalem L, Alwani MM, Rawashdeh $\mathrm{H}$ et al. Distance education during the COVID-19 outbreak: A cross-sectional study among medical students in North of Jordan. Ann Med Surg (Lond). 2020; (59): 186-194. DOI: 10.1016/j.amsu.2020.09.036.

13. Cuschieri S, Calleja AJ. Spotlight on the shift to remote anatomical teaching during covid-19 pandemic: Perspectives and experiences from the University of Malta. Anat Sci Educ. 2020; 13 (6): 671-679. doi.org/10.1002/ase.2020

14. Rizun M, Strzelecki A. Students' acceptance of the covid-19 impact on shifting higher education to distance learning in Poland. Int J Environ Res Public Health. 2020; 17 (18): 1-19. doi. org/10.3390/ijerph17186468

15. Currie G, Hewis J, Nelson T, Chandler A, Nabasenja C, Spuur K. COVID-19 impact on undergraduate teaching: Medical radiation science teaching team experience. J Med Imaging Radiat Sci. 2020; 51 (4): 518-527. DOI: 10.1016/j.jmir.2020.09.002.

16. Haroon Z, Azad AA, Sharif M, Aslam A, Arshad K, Rafiq S. COVID-19 Era: Challenges and Solutions in Dental Education. J Coll Physicians Surg Pak. 2020; (10): 129-131. DOI: 10.29271/ jcpsp.2020.supp2.129.

17. Chertoff JD, Zarzour JG, Morgan DE, Lewis PJ, Canon CL, Harvey JA. The Early Influence and Effects of the Coronavirus Disease 2019 (COVID-19) Pandemic on Resident Education and Adaptations. J Am Coll Radiol. 2020; 17 (10): 1322-1328. DOI:10.1016/j.jacr.2020.07.022. 